\title{
IMPLEMENTASI PENILAIAN AUTENTIK KURIKULUM 2013 MATA PELAJARAN EKONOMI SMAN 1 MOJOSARI MOJOKERTO
}

\author{
Elok Gita Yuliastuti \\ Economic Education Program, Faculty of Economics, State University Malang \\ egy.ghita@gmail.com
}

\begin{abstract}
This research is aiming to know authentic assessment was essential to know the success of the learning process and results. authentic assessment is a form of assessment that requires students to show attitude, using the knowledge and skills gained from learning in the conduct of the actual situation. to know how to design an authentic assessment on economic studies, implementation of authentic assessment on economic studies as well as factors of curriculum 2013 constraints authentic assessment on economic studies in SMAN 1 Mojosari, Mojokerto. The economy studies in SMAN 1 Mojosari has been implementing authentic assessment based curriculum 2013, so to be seen whether the implementation of authentic assessment conducted in SMAN 1 Mojosari have maximum and curriculum assessment in accordance with the guidelines of 2013.
\end{abstract}

Keywords: Assessment, Authentic Asessment, Curriculum 2013, Economic studies

History of Article:

Received:(11 January 2017), Accepted: (9 February 2017), Publised:(15 March 2017)

\section{Citation:}

Yuliastuti, Elok Gita (2017) Implementasi Penilaian Autentik Kurikulum 2013 Mata Pelajaran

Ekonomi SMAN 1 Mojosari Mojokerto (Implementation of authentic assessment on economic studies of curriculum 2013 in SMAN 1 Mojosari, Mojokerto) Jurnal Pendidikan Ekonomi, 10 (1), 66-72

(C) Universitas Negeri Malang 


\section{PENDAHULUAN}

Pendidikan pada hakikanya merupakan proses menumbuh kembangkan potensi-potensi kema-nusiaannya. Potensi tersebut juga meliputi kemampuan secara kognitif, kemampuan secara spiritual, kemampun emosional serta kemampuan dalam keterampilan. Potensi-potensi tersebut akan membentuk pribadi yang unggul dengan kualitas kemampuan kognitif, spiritual, emosional dan keterampilan yang baik. Hal ini terkandung dalam Undang-Undang No. 20 Tahun 2003 tentang sistem pendidikan nasional pasal 1 ayat 1 .

Dalam Undang-undang No.20 Tahun 2003 tentang sistem pendidikan nasional menjelaskan bahwa kurikulum adalah sepe-rangkat rencana dan pengaturan mengenai isi dan bahan pelajaran serta cara yang digunakan sebagai pedoman penyelenggaraan kegiatan belajar mengajar. Kurikulum disusun sebagai perangkat pendidikan yang merupakan jawaban terhadap kebutuhan dan tantangan masyarakat. Saat ini kurikulum yang berlaku di Indone-sia dalam Keputusan Menteri Pendidikan dan Kebudayaan Nomor 179342/MPK/KR/ 2014 terdapat dua jenis kurikulum yang berlaku di Indonesia yaitu kurikulum 2013 serta Kurikulum Tingkat Satuan Pendidikan (KTSP). Namun, yang masih tahap pengembangan serta evaluasi ialah Kurikulum 2013.

Dalam perkembangannya, Kurikulum 2013 merupakan kurikulum yang baru diterapkan mulai 2013/2014. Kurikulum 2013 berusaha untuk lebih menanamkan nilai-nilai yang tercermin pada sikap dapat berbanding lurus dengan keterampilan yang diperoleh dari peserta didik melalui pengetahuan di bangku sekolah. Dengan kata lain, antara soft skills dan hard skills dapat tertanam secara seimbang, berdampingan, dan mampu diaplikasi dalam kehidupan sehari-hari.

Konsep penanaman soft skills dan hard skills disisipkan dalam pembelajaran baik secara perencanaan, pelaksanaan maupun evaluasi. Ketiga hal tersebut menentukan komponen utama dalam menentukan kualitas pembelajaran sebagaimana yang diungkapkan oleh Muchtar (2010: p.71) bahwasannya Kualitas kegiatan pembelajaran dipengaruhi oleh tiga komponen utama yaitu perencanaan, pelaksanaan dan penilaian. Dalam proses evaluasi pembelajaran yang khas dalam kurikulum 2013 yaitu desain penilaian autentik yang mengombinasikan evaluasi siswa baik secara soft skills dan hard skills.

Penilaian autentik memiliki relevansi kuat terhadap pendekatan ilmiah dalam pembelajaran sesuai dengan kurikulum 2013. Kunandar (2013: p.36) dalam kurikulum 2013 mempertegas adanya pergeseran dalam melakukan penilaian, yakni dari penilaian melalui tes (mengukur kompetensi pengetahuan berdasar-kan hasil saja), menuju penilaian autentik (mengukur kompetensi sikap, keterampilan dan penge-tahuan berdasarkan proses dan hasil). Dalam penilaian autentik peserta didik diminta untuk menerapkan konsep atau teori pada dunia nyata. Autentik berarti keadaan yang sebenarnya yaitu kemampuan atau keterampilan yang dimiliki peserta didik.

Saat ini, pemberlakuan kurikulum 2013 mencapai tahap pengembangan. Berdasarkan Peraturan Menteri Nomor 179342/MPK/ KR/2014, Badan Penelitian dan Pengembangan Kemendikbud memutuskan sekitar 208.000 Sekolah Dasar (SD), 2.598 Sekolah Menengah Pertama (SMP), 1.165 Sekolah Menengah Atas (SMA), dan 1.021 Sekolah Menengah Kejuruan (SMK) di 295 kabupaten dan kota yang menjadi sekolah percontohan kurikulum 2013. Sekolah percontohan merupakan sekolah yang menerapkan dan mengembangkan kurikulum 2013 selama tiga semester terhitung sejak menginjak semester genap tahun 2014/2015 lalu. 
Penerapan ini bertujuan untuk mengembangkan dan mengevaluasi kurikulum 2013 sebagai kurikulum sekolah.

Salah satu sekolah yang menerapkan kurikulum 2013 sebagai sekolah percontohan ialah SMA Negeri 1 Mojosari, Mojokerto. Dengan ditetapkan SMA Negeri 1 Mojosari sebagai sekolah percontohan kurikulum 2013, maka sekolah tersebut mengajukan diri untuk sanggup melaksanakan kurikulum 2013. Selain itu, sekolah SMA Negeri 1 Mojosari merupakan salah satu sekolah yang terakreditasi A. Dengan menyandang status Sekolah Standar Nasional (SSN) serta sempat menyandang sebagai Rintisan Sekolah Berstandar Internasional (RSBI). Sekolah yang terletak di Kota Kabupaten Mojokerto ini mengedepankan dalam melaksanakan pendidikan formal yang membentuk sumber daya manusia yang cerdas dan berkarakter. Sama seperti tujuan dalam kurikulum 2013.

SMA Negeri Mojosari sebagai pelaksana kurikulum 2013 harus mematuhi aturan-aturan yang ditetapkan. Menurut hasil observasi awal, sekolah sudah mendapatkan pengetahuan dan pedoman pelaksanaan Kurikulum 2013 dengan melalui pelatihan. Sehingga pemahaman guru mengenai penerapan kurikulum 2013 sudah baik. Baik dalam rangka perencanaan pembelajaran maupun evaluasi pembelajaran yang diterapkan. Kurikulum sudah diterapkan mulai kelas X hingga kelas XII.

Penelitian dilakukan di semua jenjang kelas. Namun, kelas XII sedang mengantisipasi pelaksanaan Ujian Nasional berbasis komputer. Sehingga dalam prakteknya, kelas XII mengalami percepatan materi atau pemampatan materi guna persiapan Ujian Nasional. Pelaksanaan pembelajaran berdasarkan kurikulum 2013 menjadi tidak efektif. Untuk itu, dalam hal ini diharapkan pembelajaran di kelas X dan kelas XI dapat dilaksanakan lebih efektif ketimbang kelas XII.

SMAN 1 Mojosari dipilih sebagai tempat penelitian, karena SMAN 1 Mojosari telah menerapkan penilaian autentik kurikulum 2013. Menurut hasil observasi awal, mata pelajaran ekonomi telah menerapkan penilaian autentik berdasarkan kurikulum 2013, sehingga perlu dilihat apakah implementasi penilaian autentik yang dilaksanakan di SMAN 1 Mojosari telah maksimal dan sesuai dengan pedoman penilaian kurikulum 2013.

Berdasarkan konteks penelitian di atas, maka dilakukan kajian penilitian dengan judul "Implementasi Penilaian Autentik Kurikulum 2013 pada Mata Pelajaran Ekonomi di SMAN 1 Mojosari, Mojokerto".

\section{METODE PENELITIAN}

Pendekatan yang digunakan dalam penelitian ini adalah pendekatan deskriptif kualitatif. penelitiannya dilakukan pada kondisi yang alamiah (Natural setting). Jenis penelitian yang digunakan dalam penelitian ini adalah jenis penelitian fenomenalogi karena dalam pelaksanaan meliputi penjelasana berkaitan dengan pengalaman-pengalaman yang dialami oleh guru mata pelajaran ekonomi di SMA Negeri 1 Mojosari sebagai sumber data utama dalam melaksanakan kegiatan penilaian pembelajaran ekonomi berdasarkan Kurikulum 2013. Fokus masalah dalam penelitian ini adalah perencanaan penilaian autentik, pelaksanaan penilaian autentik serta faktor-faktor yang menjadi kendala penilaian autentik berdasarkan kurikulum 2013. Subyek penelitian ini ialah guru mata pelajaran ekonomi kelas X dan Kelas XI di SMA Negeri 1 Mojosari. 
Data penelitian berupa data primer dengan menggunakan teknik wawancara, dokumentasi serta observasi. Instrumen yang digunakan untuk mengumpulkan data berupa instrumen manusia, yaitu peneliti sendiri.

\section{HASIL DAN PEMBAHASAN \\ Perencanaan Penilaian Autentik}

Menurut Pusat Kurikulum dalam Hartati Muhtar "(authentic assesment) merupakan suatu proses pengumpulan, pelaporan dan penggunaan informasi tentang hasil belajar siswa dengan menerapkan prinsip-prinsip penilaian, pelaksanaan berkelanjutan, bukti-bukti autentik, akurat, dan konsisten sebagai akuntabilitas public (Muchtar; 2010: p.72).

Perencanaan penilaian autentik kurikulum 2013 pada mata pelajaran ekonomi di dalam bentuk Rencana Pelaksanaan Pembelajaran sudah sesuai. RPP kelas X mengenai sistem pembayaran serta RPP kelas XI mengenai pasar modal juga memuat semua penilaian. Baik penilaian pengetahuan, penilaian keterampilan serta penilaian sikap. Ini sesuai dengan Permendikbud No.104 Tahun 2014 tentang penilaian hasil belajar oleh pendidik pada pendidikan dasar dan pendidikan menengah yaitu penilaian autentik adalah bentuk penilaian yang menghendaki peserta didik menampilkan sikap, menggunakan pengetahuan dan keterampilan yang diperoleh dari pembelajaran dalam melakukan tugas pada situasi yang sesungguhnya.

Kedua RPP juga sesuai dengan pedoman penyususnan RPP yang berpedoman pada permendikbud No. 103 Tahun 2013 yaitu (1) 1) identitas sekolah/madrasah, mata pelajaran, dan kelas/semester; (2) alokasi waktu; (3) KI, KD, indikator pencapaian kompetensi; (4) materi pembelajaran; (5) kegiatan pembelajaran; (6) penilaian; dan (7) media/alat, bahan, dan sumber belajar. Memuat prinsip penyusunan RPP yaitu (1) Setiap RPP harus secara utuh memuat kompetensi dasar sikap spiritual (KD dari KI-1), sosial (KD dari KI-2), pengetahuan (KD dari KI-3), dan keterampilan (KD dari KI-4). (2) Satu RPP dapat dilaksanakan dalam satu kali pertemuan atau lebih. (3) Memperhatikan perbedaan individu peserta didik (4) Berpusat pada peserta didik. (5) Berbasis konteks (6) Berorientasi kekinian. (7) Mengembangkan kemandirian belajar (8) Memberikan umpan balik dan tindak lanjut pembelajaran (9) Memiliki keterkaitan dan keterpaduan antarkompetensi dan/atau antarmuatan (10) Memanfaatkan teknologi informasi dan komunikasi.(11) Komponen dan Sistematika RPP.

\section{Pelaksanaan Penilaian Autentik}

Pelaksanaan penilaian Autentik pada kelas X serta kelas XI sudah dilaksanakan dengan baik. Setiap penilaian, baik penilaian sikap, pengetahuan dan keterampilan juga sudah dilaksanakan dengan guru. Sikap dinilai berdasarkan indikator pada Kompetensi Inti I yang berbunyi:" Menghayati dan mengamalkan ajaran agama yang dianutnya," Guru menilai berdasarkan sikap yang ditunjukkan siswa melalui observasi yang ditunjukkan.Kompetensi Inti I yang lebih bersifat keagamaan ditunjukkan dengan setiap akan memulai aktifitas belajar mengajar selalu melakukan doa bersama dibimbing oleh guru agama melalui pengeras suara. Sama halnya dengan Kompetensi Inti II yang berbunyi "Menghayati dan mengamalkan perilaku jujur, disiplin, tanggung jawab, peduli (gotong royong, kerja sama, toleran, 
damai), santun, responsif, dan pro aktif dan menunjukkan sikap sebagai bagian solusi atas berbagai permasalahan dalam berinteraksi secara efektif dengan lingkungan sosial dan alam serta dalam menempatkan diri sebagai cerminan bangsa dalam pergaulan dunia"

Kompetensi Inti I dicerminkan guru dengan menilai sikap siswa.Guru mengamati siswa dan menilai sesuai dengan kriteria penilaian sikap. Guru juga mengamati siswa di saat diskusi untuk dinilai dengan menggunakan penilaian sikap. Baik saat siswa berada di kelompoknya maupun siswa berada dalam kegiatan presentasinya.

Guru juga melaksanakan penilaian pengetahuan dalam pembelajaran. Dalam Kompetensi Inti III yang berbunyi "Memahami, menerapkan, menganalisis pengetahuan faktual, konseptual, prosedural berdasarkan rasa ingin tahunya tentang ilmu pengetahuan, teknologi, seni, budaya, dan humaniora dengan wawasan kemanusiaan, kebangsaan, kenegaraan, dan peradaban terkait penyebab fenomena dan kejadian serta menerapkan pengetahuan prosedural pada bidang kajian yang spesifik sesuai dengan bakat dan minatnya untuk memecahkan masalah,"

Guru melakukan berbagai instrumen penilaian guna menilai aspek pengetahuan siswa. Instrumen yang dipakai guru di kelas $\mathrm{X}$ dan XI ialah penilaian tes lisan serta penugasan. Instrumen tes lisan tercermin dari tanya jawab guru dengan siswa yang aktif saat guru menjelaskan materi. Guru mencatat siswa yang aktif dalam menjawab pertanyaan guru serta aktif dalam mengungkapkan pendapatnya yang menyangkut materi.

Guru juga melakukan penilaian dari aspek keterampilan dalam Kompetensi Inti IV yang berbunyi:" Mengolah, menalar dan menyaji dalam ranah konkret dan ranah abstrak terkait dengan pengembangan dari yang dipelajarinya di sekolah secara mandiri dan mampu menggunakan metode sesuai kaidah keilmuan,".

Instrumen yang digunakan dalam menilai penilaian keterampilan melalui proyek yang berbentuk penilaian presentasi yang dilakukan di muka kelas. Guru memberikan penghargaan bagi siswa yang aktif sebagai bentuk apresiasi dalam keaktifan di kelas pada saat presentasi sebagai penilaian dalam keterampilan.

\section{Faktor-faktor kendala Penilaian Autentik}

Penilaian autentik kurikulum 2013 pada mata pelajaran ekonomi di SMAN 1 Mojosari banyak mengalami kendala. Baik faktor-faktor eksternal maupun internal. Faktor eksternal yang terjadi ialah banyaknya penilaian yang dilakukan. Penilaian yang dilakukan terlalu banyak sehingga waktu yang dibutuhkan dalam melakukan penilaian juga banyak. Guru kesulitan dalam mengatasi hal tersebut. Selain itu, Kondisi psikologis siswa mempengaruhi objektivitas dalam pemberian skor. Noviyanti et al. (2014) yang menyatakan bahwa siswa masih kurang objektif untuk menilai teman maupun dirinya sendiri.

Selain faktor eksternal, faktor internal juga menjadi kendala dalam penilaian autentik. Ada beberapa Siswa secara personal tidak memperhatikan guru sehingga bila guru melakukan penilaian, siswa cenderung memperlama guru dalam menilai siswa. Hal ini sesuai dengan hasil penelitian Gahara (2016) bahwasannya hambatan dalam pelaksanaan penilaian autentik adalah kemampuan dasar anak yang masih memerlukan bimbingan. Siswa belum terbiasa belajar secara mandiri. Kerepotan guru dalam menghadapi jumlah siswa yang banyak. Banyaknya indikator yang harus dinilai secara detail. 
Guru berupaya dalam mengatasi kendala-kendala dalam penilaian autentik. Guru sebisa mungkin mengatasi hal tersebut sendiri, dalam hal ini tidak melibatkan pihak lain. Baik mengatasi kendala eksternal maupun internal. Ini disebabkan guru merasa kelas yang diajar hanya guru yang mengetahui karakteristik siswa. Dalam solusi yang terakhir pada kendala internal ialah guru mencoba berkordinasi dengan wali kelas guna mengatasi kendala yang terjadi pada siswa yang bersangkutan dalam hal ini siswa sebagai obyek yang dinilai guru.

Guru berharap perbaikan dalam sistem penilaian autentik yang lebih fleksibel. Agar guru melakukan penilaian juga dapat memaksimalkan penilaian kepada siswa. Terutama yang berkaitan dengan waktu yang dapat dimanfaatkan secara maksimal. Walaupun, bagi guru penilaian autentik saat ini sudah baik, namun ada beberapa hal-hal yang perlu disempurnakan untuk mewujudkan tujuan pendidikan.

\section{KESIMPULAN}

Berdasarkan hasil analisis dan pembahasan yang telah diuraikan dalam penelitian ini, maka didapatkesimpulan sebagai berikut: 1) Perencanaan penilaian autentik kurikulum 2013 pada mata pelajaran ekonomi di dalam bentuk Rencana Pelaksanaan Pembelajaran sudah sesuai dengan pedoman penyusunan RPP permendikbud No. 103 Tahun 2013 dan ciri-ciri penilaian autentik dalam kurikulum 2013 dalam Penyusunan penilaian dalam Rencana Pelaksanaan Pembelajaran (RPP) kelas X sistem pembayaran dan alat pembayaran dan kelas XI bab pasar modal sudah memuat tiga jenis penilaian. Yaitu penilaian sikap, penilaian pengetahuan serta penilaian keterampilan; 2) Pelaksanaan penilaian autentik kurikulum 2013 pada mata pelajaran ekonomi di SMAN 1 Mojosari sudah baik. Ini dibuktikan Setiap penilaian, baik penilaian sikap, pengetahuan dan keterampilan juga sudah dilaksanakan dengan guru. Guru mengamati siswa dan menilai sesuai dengan kriteria penilaian sikap. Ini sesuai dengan kompetensi Inti yang diukur melalui penilaian yang sesuai dengan Permendikbud No.81 A tentang implementasi kurikulum 2013; 3) Penilaian autentik kurikulum 2013 pada mata pelajaran ekonomi di SMAN 1 Mojosari banyak mengalami kendala. Baik faktor-faktor eksternal maupun internal. Faktor eksternal yang terjadi ialah banyaknya penilaian yang dilakukan. Penilaian yang dilakukan terlalu banyak sehingga waktu yang dibutuhkan dalam melakukan penilaian juga banyak. Guru kesulitan dalam mengatasi hal tersebut.Selain faktor eksternal, faktor internal juga menjadi kendala dalam penilaian autentik. Ada beberapa Siswa secara personal tidak memperhatikan guru sehingga bila guru melakukan penilaian, siswa cenderung memperlama guru dalam menilai siswa. Guru berupaya dalam mengatasi kendala-kendala dalam penilaian autentik. Dalam solusi yang terakhir pada kendala internal ialah guru mencoba berkordinasi dengan wali kelas guna mengatasi kendala yang terjadi pada siswa yang bersangkutan dalam hal ini siswa sebagai obyek yang dinilai guru.

Berdasarkan kesimpulan di atas, maka saran yang dapat penulis berikan yaitu: 1) Bagi Guru Ekonomi: Sebaiknya guru ekonomi berdiskusi dengan guru ekonomi lain baik guru SMAN 1 Mojosari maupun guru sekolah lain dalam mengatasi kendala penilaian di dalam kelas serta melakukan manajemen waktu dalam melakukan penilaian autentik; 2) Bagi peneliti selanjutnya: Sebaiknya peneliti selanjutnya meneliti dan mengkaji lebih mendalam mengenai penilaian autentik; 3) Bagi Sekolah: Sebaiknya sekolah mengadakan workshop dalam memperdalam pemahaman guru mengenai penilaian autentik serta melakukan workshop manajemen waktu. 


\section{DAFTAR PUSTAKA}

Gahara, Budiarti (2016) Implementasi Penilaian Autentik Pada Pembelajaran Pendidikan Agama Islam Kurikulum 2013. Jurnal Penelitian Manajemen Pendidikan (TANZIM). Vol.1 No.1 Tahun 2016

Keputusan Kepala Badan Penelitian dan Pengembangan Tentang Penetapan Satuan

Pendidikan Pelaksana Kurikulum 2013. 2014. Jakarta: Kementrian Pendidikan dan Kebudayaan

Kunandar (2013) Penilaian Autentik (Penilaian Hasil Belajar Peserta Didik Berdasarkan Kurikulum 2013. Jakarta: Raja Grafindo

Muchtar, H (2010) Penerapan Penilaian Autentik dalam Upaya Peningkatan Mutu Pendidikan. Jurnal Pendidikan Penabur,9 (14) : 68-76.

Muchtar, Hartati. (2010) Penerapan Penilaian Autentik dalam Upaya Peningkatan Mutu Pendidikan, Jurnal Pendidikan Penabur - No.14/Tahun ke-9/Juni 2010,

Noviyanti, L (2014) Pengembangan Instrumen Self dan Peer Assessment Berbasis Literasi Sains di Tingkat SMA. Lembaran Ilmu Kependidikan. 43(1): 32-39. Tersedia di http://journal.unnes.ac.id/nju/index.php/LIK

Peraturan Menteri Pendidikan dan Kebudayaan Nomor 103 Tahun 2014 tentang Penilaian Hasil Belajar oleh Pendidik pada Pendidikan Dasar dan Pendidikan Menengah.2013. Jakarta : Kementrian Pendidikan dan Kebudayaan

Peraturan Menteri Pendidikan dan Kebudayaan Nomor 104 Tahun 2014 tentang Penilaian Hasil Belajar oleh Pendidik pada Pendidikan Dasar dan Pendidikan Menengah.2013. Jakarta : Kementrian Pendidikan dan Kebudayaan Undang-undang Nomor 20 Tahun 2003 Tentang Sistem Pendidikan Nasional 